\title{
Horta, Juan José. La última noche. Bogotá: Publicación independiente, 2018. Reseña
}

\author{
Carlos Mario Fisgativa ${ }^{1}$ \\ Juan Manuel Díaz Leguizamón ${ }^{2}$
}

1 Magíster en filosofía por la Pontificia Universidad Javeriana (Colombia). Grupos de investigación: 1) Blanchotianxs del Sur. Proyecto: Naturaleza no humana y naturaleza en lo humano. Nuevas perspectivas a partir de lecturas críticas del materialismo posthumano. Instituto de filosofía, Universidad de Buenos Aires (Argentina). 2) Literaturas marginales -Marginalia. Relecturas del canon literario. Facultad de educación de la Universidad del Quindío (Colombia). Proyecto: Procesos de creación literaria desde las nuevas narrativas (o narrativas transmedia). Correo electrónico: carlosmfisgativa@hotmail.com.

2 Magíster en Filosofía por la Pontificia Universidad Javeriana (Colombia). Docente de la facultad de filosofía de la Pontificia Universidad Javeriana y de la carrera de filosofía de la Universidad del Bosque. Correo electrónico: polixetes@hotmail.com. 
$L$ a última noche es un catálogo fotográfico lanzado en 2018 por el artista vallecaucano Juan José Horta, fruto de una edición e impresión independientes, llevadas a cabo mediante microfinanciación colectiva (crowfunding).

El trabajo presenta de modo alternativo una de tantas instancias del proceso de paz en Colombia, culminado protocolariamente con la firma del acuerdo de septiembre de 2016: un episodio de desmovilización y entrega de armas por parte de miembros del grupo rebelde al margen de la ley Fuerzas Armadas Revolucionarias de Colombia (FARC). Por tanto, La última noche se enmarca en la temática del llamado pos-conflicto.

La obra consiste en una secuencia de 17 fotografías a color, de armas de asalto depositadas sobre superficies planas cubiertas por frazadas, como camas perfectamente tendidas. Estas fotografías se encuentran dispuestas de modo tal que se despliegan a la manera de un friso. La totalidad de estas imágenes arma, desde el respaldo de cada una de ellas, una gran imagen englobante que cierra el libro como una especie de sumatoria y conclusión. En ella aparece un contorno vacío que delinea la silueta de una de estas armas sobre una sábana blanca y arrugada. Como anexo se incluye la reproducción de dos cartas de excombatientes, manuscritas en modestas hojas de cuaderno. Estas no son páginas como tales del catálogo sino que se encuentran depositadas en una solapa lateral. Se trata de testimonios de personas que tuvieron a su cargo algunas de estas armas durante su participación en el conflicto y que se despiden de ellas como condición para empezar una nueva vida.

Otra característica llamativa del catálogo es la ausencia de textos que acompañen las imágenes. Este gesto usualmente obedece a una expresa renuncia y renuencia a describir, contextualizar, comentar o explicar el material visual (Derrida, "Artes" 267-268). No incluye pies de página, ni un prólogo, ni conclusiones. Tampoco tiene índice, segmentación por partes, o una estructura distinta a la misma configuración de las fotos en su mero aparecer. Podemos concebir en ello una especie de confianza depositada en la potencia de las imágenes para funcionar por sí solas, aunque esta función no quede definida de antemano, pues las posibilidades para activar potencias heterogéneas quedan abiertas: sea potencias de significación, de conmoción emocional, de vibración, de expresividad o de información, esta multiplicidad puede verse 
como la contribución a (re)construir la memoria de un pasado y proponer los esbozos de un futuro (Didi-Huberman, "Sublevaciones" 35). Además, esta confianza depositada en la imagen se hace extensiva al espectador, el cual se abandona y se deja libre para ejercer su potencia perceptiva e interpretativa única. Cada observador debe acudir a su personal conocimiento de la historia y del conflicto colombiano, al bagaje de sus herramientas conceptuales, a su propia capacidad de atención al detalle y a su juicio acerca del posible sentido de la obra, sin contar con mayores direccionamientos u orientaciones externas. Con excepción de dos aspectos: por un lado, el título de la obra y, por el otro, cartas testimoniales cargadas de rastros autobiográficos.

No obstante, tanto el título como las cartas funcionan a la manera de fragmentos, los cuales a su vez pueden hacer las veces de huellas muy tenues que apenas sugieren una historia y un destino (Benjamin 50) asignable a esos objetos, silentes pero capturados en su presencia por la cámara, y a sus poseedores, invisibles pero presentes en su palabra. La primera carta, firmada por Juan José Viya, comunica a su arma que "te bas de mis manos pero no te bas de mi mente, te recordaré y te irás a descanzar" (sic). La segunda, firmada por "David", recuerda a su arma que "me acompañaste hombro a hombro, noche tras noche". El título recoge y combina estas afirmaciones con una expresión que se mueve en la ambigüedad; hablar desde la certeza de una sentencia definitiva y desde la esperanza de un deseo sin garantías: "La última noche". Vale preguntarse: ¿la última noche de qué o de quién?

Y es que cada una de las armas de la serie aparece delicadamente depositada en una superficie cubierta con mantas coloridas y de motivos pintorescos. Una estética casi kitsch, sin pretensiones, recuerda los cobertores de camas de personas sencillas pertenecientes a clases humildes de las ciudades y regiones de Colombia. Y depositadas sobre ellas, es como si cada arma pasara del vértigo de su funcionalidad bélica, de la cotidianidad de su accionar de muerte, a abrazar por fin el descanso eterno de los objetos jubilados y obsoletos, liberados de su instrumentalidad (Bodei, 160-161). El sentimentalismo cursi, el diseño fácil, la luminosidad chillona y la función de cobijo y calor de los cobertores, contrasta con la oscuridad siniestra encarnada en la frialdad de las máquinas de guerra, su hostilidad violenta y su capacidad desintegradora, emanada de la efectividad garantizada por su complejidad técnica. 
Entonces comprobamos que aunque la obra no presente un mensaje explícito ni una narrativa ordenada bajo la lógica del discurso, esto no implica que carezca de información. La particularidad es que esta información se encuentra codificada bajo otra forma: la de la imagen (Didi-Huberman, "Lo que vemos" 17). Por eso tampoco carece de carácter testimonial, sino que, en vez de presentar una versión de la historia en la aparente coherencia de un cuerpo de proposiciones o argumentos, moviliza los afectos de un pasado, disperso en unos objetos cuyo conjunto puede componerse de muchas maneras, esbozando entonces al tiempo una imagen de pasado que precisamente se pretende abierto, inconcluso y problemático. Por eso, sostenemos que la obra activa una mirada crítica pues, a la vez que despliega numerosos cuestionamientos acerca de la historia reciente del país, también lo hace acerca de las condiciones de la figurabilidad, de la representación y del carácter de monumento de cualquier documento (Benjamin 46; Uribe 98).

Y es que es peligroso tratar de consolidar una imagen monolítica del pasado. Eso conllevaría dejar de lado lo irreductible de las singularidades de cada una de las piezas que conforma la realidad, así como la posibilidad de que esta toma múltiples formas distintas y válidas. El respeto por la singularidad se observa en el hecho de que ninguna de las armas retratadas se repite. Cada una exhibe las marcas de sus avatares únicos: peladuras, rayones y desgastes; diferentes modelos y marcas; intervenciones personales que proceden de la identidad de sus dueños, como nudos, cordones, ganchos y adaptaciones diversas. Tampoco se repite ningún cobertor. Sus diseños y colores son variados: desde corazones, pasando por flores y plantas, animales, paisajes, imitación de piel y hasta formas geométricas abstractas. Todas tienen en común, eso sí, que dan cuenta de cierta inocencia en la composición y en el estilo que, como ya dijimos, contrasta fuertemente con el aspecto terrible de una máquina que utiliza todo el ingenio humano para lograr un diseño mortífero.

Un comentario aparte merece la imagen que resulta de la sumatoria del anverso de las otras. Como un epítome, parece invocar un problema que ha torturado siempre a la teoría de la imagen, y que dista de ser meramente estético, pues incluye dimensiones éticas y políticas (Urueña, 100-101). Se trata del dilema de si representar o no la violencia, sobre todo cuando al decidir hacerlo es muy fácil caer en la mala práctica de revivir el dolor y la injusticia causados por ella, o peor aún, banalizarlo, normalizarlo o anestesiarlo. En este caso la obra toma una vía casi mística, en el buen sentido del término. Resuelve 
la paradoja sin renunciar a representar, pero tampoco representando solo explícitamente. Después de mostrar las diferentes armas en su positividad y su aparecer, se "muestra" el espacio dejado por una presencia que ya no hace falta preservar. La imagen muestra una sábana blanca, cuyas sutiles arrugas esbozan el contorno del fusil, dejado ahí por el peso del objeto que ya no está. Es imposible no asociar esta imagen con otra que ha tenido una larga carrera en la iconografía, la del santo sudario (Didi-Huberman comentando a Aby Warburg, "Sublevaciones" 87), el cual reproduce la impresión dejada por un cuerpo sacrificado cuya ausencia se convierte en una promesa de paz y reconciliación. Es el equivalente, en imagen, a un silencio. En este caso, el silenciamiento del fuego de la destrucción, solo posible después de mucha sangre, renuncias y derrotas.

Este fotolibro nos posiciona así ante imágenes de un pasado que en su aparecer necesariamente debe hacer lugar al vacío y al misterio, pues surge desde el revés de fragmentos explícitamente representados pero en sí mismos insuficientes. Es una muestra de que la construcción del pasado solo puede surgir tras una decisión compositiva, del montaje de fragmentos y el cruce de series de hechos y situaciones teóricamente inagotables (Derrida, "Mal" 12).

La última noche se suma así a un archivo de imágenes en expansión, destinado a mantener viva la memoria del pasado violento de nuestro país, con el propósito de construir un porvenir distinto. Esto mediante el aporte de unas nuevas piezas que ayuden a seguir armando el rompecabezas cambiante y en perpetua renovación de nuestra historia.

\section{Lista de referencias}

Benjamin, Walter. “Tesis de filosofía de la historia”. En Ensayos escogidos, (43-52). México: Ediciones Coyoacan, 2001.

Bodei, Remo. La vida de las cosas. Madrid: Amorrortu, 2013.

Derrida, Jacques. Mal de Archivo. Impresiones Freudianas. Madrid: Trotta, 1997.

Derrida, Jacques. Artes de lo visible (1979-2004), trad. J Masó, J. Bassas. España: El Lago Ediciones, 2013.

Díaz, Juan Manuel. “Teoría mimética y américa latina: el vigente problema de la identidad, un diálogo que nos convoca”. En: Cuadernos de Filosofía Latinoamericana 39.118 (2018):143-158. 
Didi-Huberman, Georges. La venus rajada. Madrid: Losada, 2005.

Didi-Huberman, Georges. Lo que vemos, lo que nos mira. Buenos Aires: Manantial, 1997.

Didi-Huberman, Georges. Sublevaciones. Buenos Aires: Eduntref, 2017.

Fisgativa, Carlos. "Lenguaje y alegoría. Modos de considerar el arte a partir de Walter Benjamin”. En: Revista de filosofía UIS 15.2 (2016):137-155.

Horta, Juan José. La última noche. Bogotá: Publicación independiente, 2018.

Uribe, María Victoria. “¿Los fantasmas no inquietan nunca a las cosas muertas? Entre el Terror y el desaliento en Colombia”. En: Revista M 3. 5. (2018): 92-102.

Urueña, Juan. El montaje en Aby Warburg y en Walter Benjamin: un método alternativo para la representación de la violencia. Bogotá: Universidad del Rosario, 2017.

Warburg, Aby. La primavera de Boticelli. Madrid: Casemiro, 2013. 